\title{
Constraints Faced by the Farmers in Adoption of Soil Health Card Scheme
}

\author{
Sheetal, Manmeet Kaur* and Diksha Sharma \\ Department of Agricultural Extension and Communication, College of Agriculture, Swami \\ Keshwanand Rajasthan Agricultural University, Bikaner-334006, India \\ *Corresponding author
}

\begin{tabular}{|l|}
\hline K e y w o r d s \\
Constraints, \\
$\begin{array}{l}\text { Farmers, Adoption } \\
\text { and Soil health card } \\
\text { scheme }\end{array}$ \\
\hline Article Info \\
\hline $\begin{array}{l}\text { Accepted: } \\
\text { 04 August } 2020 \\
\text { Available Online: } \\
\text { 10 September } 2020\end{array}$ \\
\hline
\end{tabular}

\section{A B S T R A C T}

\begin{abstract}
Major part of Indian economy is contributed by agriculture and its allied sector. Around 56 per cent of population directly or indirectly depends upon agriculture. The GDP contribution of the agriculture and allied sector is 17.2 per cent, but this sector is facing many challenges to flourish. Out of these challenges lesser crop productivity and inefficient use of fertilizers are the main challenges faced by Indian farmers. Till now, fertilizer recommendations for different crops are made on the basis of agronomical practices and not on the soil test basis. This has led to nutritional deficiencies and decrease in soil fertility in some parts of the country. Hence, to improve the soil health and boost productivity it has become necessary to nurture the soil. In the wake of this, Government has launched the soil health card scheme in February, 2015 to take care of soil health in a uniform pattern for the first time in order to evaluate the soil fertility across the country by the Government of India in cooperation with state governments. This study was an attempt to analyze the constraints being faced by the farmers in the adoption of Soil Health Card Scheme (SHCs). The present study was conducted in Sri Ganganagar district of Rajasthan state which was selected purposely. The Sri Ganganagar district consists of nine tehsils, Out of these, three tehsils namely Padampur, Sadulshahar and Karanpur were selected purposely for the present investigation on the basis of highest number of registered farmers under SHCs. The proportionate random sampling method was used to select the registered farmers and they were called as beneficiary of Soil Health Card scheme because they have benefited under Soil Health Card Scheme. Further, equal number of non-beneficiary respondents from same tehsils were also selected randomly who have not benefited under Soil Health Card scheme and they were called as non-beneficiary respondents. Thus, total 120 respondents i.e. 60 beneficiary and 60 non-beneficiary respondents were selected from selected tehsils for the present investigation. The findings of the study revealed that the most important constraints being faced by the respondents in the adoption of Soil Health Card scheme were "lack of knowledge about the importance of micronutrients", "lack of mobile soil testing vans", "unavailability of micronutrient in market" and "lack of motivation".
\end{abstract}

\section{Introduction}

Economic development and growth in developing countries like India depends crucially upon the progress of agricultural production having a larger share in national income, employment and export earnings. India having two per cent of world's 
geographical area has the responsibility to feed a populace of 130 crores which is roughly 18 per cent of world's total population. Since we got independence, food grains production in our country has been constantly increasing and has reached to 277.49 million tonnes in $2017-18$ which is more than about five times the 50.8 million tonnes in 1950-51 (Anonymous, 2018). The food grains area per person was 0.22 hectare during 1950 which had declined to 0.10 hectare during 2000 and it has been estimated to be falling to 0.06 hectare in 2050 . Therefore, in developing countries like ours, with such a population pressure, the efficient use of fertilizer must go hand-in-hand for a better tomorrow. To cope with the situation, the agricultural production can be enhanced either by bringing more area under cultivation or through increasing productivity. In our country, land is becoming a limited resource with its demand increasing like never. This source being the limited one is shrinking day by day. The cultivated area in our country is about 145 million hectares and this area has been constant since last few years. As we cannot increase the net sown area due to certain limitations, it would be difficult to bring additional areas under cultivation so as to feed the teeming millions posing a huge challenge for us. Our natural resources have been depleting and failing to serve this ever increasing mass of people. Hence, in order to fulfill the need based goals of agricultural production, the production enhancement patterns will have to rely largely on increased productivity. The only thing that we can do is optimizing the usage of the existing farm land by adoption of new strategies for agricultural development. The need of the hour is to shift from extensive cultivation to intensive mode of cultivation where maximum outputs can be derived from the same piece of land. Fertilizer usage being the key component of the food grain production cycle, contributed to about 50 per cent of increased food-grains production in the world (Hegde and Sudhakarbabu, 2004 and Tanwar and Bisvas, 2005). In India, fertilizer consumption is focused in about on one-third of the cultivated area. Farmers often apply too much heavily subsidized urea while seldom, if ever, applying secondary nutrients (for example, sulfur, calcium and magnesium) or micronutrients (for example, zinc, iron, copper, boron, molybdenum and manganese) the over application of urea has resulted in a highly skewed NPK application ratio of $8: 2: 3: 2: 1$, compared with the broadly recommended ratio of $4: 2: 1$ (Anonymous, 2015). This scenario has critically resulted in declining vitality of Indian soils and as a result of the same, threat to food security has been accepted as a crisis by Indian policy makers (Gopikrishna, 2012).

Soil is an important component of farming and foundation source of nutrients for cultivation of crops. Hence, to improve the soil health and boost productivity it has become necessary to nurture the soil. In the wake of this, Government has launched the soil health card scheme in February, 2015. Under this scheme farmers are issued a soil health card which carries crop-wise recommendation of nutrients and fertilizer requirement for individual farm. Soil health card can also be understood as a performance card where the farmer gets to know the condition of soil. All soil samples are to be tested by the experts in different soil testing labs across the country. After testing the samples, the experts will analyze the strength and weakness (micro-nutrients deficiency) of the soil and suggest measures to deal with it. It also provides crop-wise fertilizer recommendations. Soil health card makes the farmers aware about the soil health on their farms and motivates them to improve productivity by maintaining soil health. So, realizing the importance of soil health in agriculture production, the present study was 
conducted with the objective to delineate the constraints being faced by the farmers in the adoption of Soil Health Card scheme.

\section{Materials and Methods}

The present study was conducted in Sri Ganganagar region of Rajasthan state which was selected purposely because this scheme was first launched in Sri Ganganagar region of Rajasthan. Sri Ganganagar region comprises of two districts namely Sri Ganganagar and Hanumangarh. Out of these two districts, Sri Ganganagar district was selected purposely for the present investigation on the basis of highest number of registered farmers under Soil Health Card scheme. Three tehsils namely Padampur, Karanpur, Sadulsahar were purposely selected for the present investigation on the basis of highest number of registered farmers under Soil Health Card scheme. For selection of respondents, a comprehensive tehsil-wise list of farmers who were having soil health card was procured from the Department of Agriculture, Sri Ganganagar, Rajasthan.

The proportionate random sampling method was used to select the respondents who were having soil health card and they were called as beneficiary of Soil Health Card scheme. To constitute the other half of sample size same number of farmers were also selected from the above tehsils who were not having soil health card and they were called as nonbeneficiary respondents. Thus, total 120 respondents i.e. 60 beneficiary and 60 nonbeneficiary respondents were selected from selected tehsils for the present investigation. Thus, the total sample size from the selected three tehsils was 120 respondents. The data were collected with the help of pretested semi-structured interview schedule. Analysis of the data was done with the help of different statistical tools like mean percent score, rank correlation, $\mathrm{t}$-test etc.

\section{Results and Discussion}

According to Business Dictionary constraint is that, who restricts an entity, project or system (such as a manufacturing or decision making process) from achieving its potential (or higher level of output) with reference to its goal. To measure the constraints responsible for hindering the adoption of Soil Health Card scheme by respondents, a suitable schedule was developed for the present investigation. All the possible constraints being faced by the beneficiary and non-beneficiary farmers were grouped into four major categories viz. technical, administrative, marketing and socio-personal and psychological constraints. In order to study various types of constraints, the respondents were asked to give the response on three point continuum. After that on the basis of scores in each category of constraint mean per cent score was calculated for each dimension.

\section{Technical constraints}

The data in Table 1 reveals that technical constraints viz. 'improper information about micronutrient status in soil' which was ranked first (50.00 MPS) by beneficiary respondents followed by 'lack of knowledge about the importance of micronutrients' second (45.44 MPS) and 'lack of knowledge about scientific method of collection of soil sample' had ranked third (36.11 MPS), 'time gap between soil sample taken and issuing card is very long' was ranked fourth (30.50 MPS), respectively. Whereas, in case of nonbeneficiary and overall respondents the first rank was assigned for 'lack of knowledge about the importance of micronutrients with 87.55 MPS and 66.49 MPS followed by 'improper information about micronutrient status in soil' with 80.66 MPS and 65.33 MPS, 'time gap between soil sample taken and issuing card is very long' with 78.77 MPS 
and 54.63 MPS and 'lack of knowledge about scientific method of collection of soil sample' with 52.77 MPS and 44.44 MPS were ranked second, third, and fourth, respectively.

The value of rank correlation $\left(r_{s}\right)$ between beneficiary and non-beneficiary was 0.6 which was found non-significant at five per cent level of significance, leading to conclusion that there was a similarity in rank assignment pattern of technical constraints of beneficiary and non-beneficiary farmers about Soil Health Card scheme, though there was a difference in the magnitude of MPS of beneficiary and non-beneficiary farmers.

Thus, from the above findings it may be concluded that majority of the respondents reported that lack of knowledge about the importance of micronutrients, improper information about micronutrient status in soil and time gap between soil samples taken and issuing card is very long were the major constraints. This might be due to the reason that farmers in the study area lacked knowledge about SHCs. The findings are in line with the findings of Patel (2013) and Lamkane (2018) who found that unavailability of nutrient status in soil followed by difficulty in calculating fertilizer dose, lack of systematic training, time gap between soil sample taken and issuing card is long were the major constraints faced by the farmers in the adoption of SHC.

\section{Administrative constraints}

The data in Table 2 depicts that major constraints faced by beneficiary farmers were 'lack of mobile soil testing vans' (80.55 MPS) which was ranked first followed by 'unavailability of soil health report at the time of crop sowing' (64.44 MPS), 'no soil testing lab available in nearby areas (53.33 MPS) was ranked second and third respectively, 'unavailability of agricultural supervisor' (43.88 MPS) was ranked fourth and 'connive by agricultural department' (42.22 MPS) was at last position.

Further examination of the Table 2 reveals that the major constraints perceived by the non-beneficiary respondents were 'lack of mobile soil testing vans' (98.33 MPS) was ranked first followed by 'no soil testing lab available in nearby areas' (97.77 MPS) was ranked second, 'unavailability of soil health report at the time of crop sowing' (88.88 MPS) was ranked third, 'connive by agricultural department' (81.11 MPS) was ranked fourth and 'unavailability of agricultural supervisor' (72.22 MPS) was ranked fifth. If we look at the data in Table 2 irrespective of beneficiary and nonbeneficiary respondents, data reveals that major constraints perceived by the overall respondents were 'lack of mobile soil testing vans' (89.44 MPS) followed by 'unavailability of soil health report at the time of crop sowing' (76.66 MPS) were ranked first and second respectively. While, no soil testing lab available in nearby areas (75.55 MPS) was ranked third and connive by agriculture department (61.66 MPS) was ranked fourth. The constraint viz. "unavailability of agricultural supervisor (58.05 MPS) was perceived least important by the overall respondents in the study area as they had assigned last rank to this constraint. Here, the value of calculated rank correlation $\left(r_{\mathrm{s}}\right)$ was 0.80 which was positive and significant at five per cent level of significance, leading to conclusion that there was a similarity in rank assignment pattern of administrative constraints of beneficiary and non-beneficiary farmers about soil health card scheme, though there was a difference in the magnitude of MPS of beneficiary and nonbeneficiary farmers. The findings are in accordance with the finding of Bunkar (2018) who concluded that lack of mobile soil testing vans and absence of soil testing laboratories were the major lacunas faced by the respondents. 


\section{Marketing constraints}

The data in Table 3 depicts that major constraints faced by beneficiary farmers were 'price of fertilizers is high (48.88 MPS) which was ranked first followed by 'unavailability of micronutrient in market (47.22 MPS), 'sometimes adequate quantity of fertilizers are not available in the market (38.88 MPS) was ranked second and third respectively and nonavailability of NPK combination fertilizer (37.77 MPS) was ranked fourth at last position.

Further examination of the Table 3 reveals that the major constraints perceived by the non-beneficiary respondents were 'unavailability of micronutrient in market' (67.22 MPS) was ranked first followed by 'price of fertilizers is high (62.77 MPS) was ranked second, "non-availability of NPK combination fertilizer' (62.22 MPS) was ranked third, sometimes adequate quantity of fertilizers are not available in the market' (57.77 MPS) was ranked fourth, respectively. If we look at the data in Table 3 irrespective of beneficiary and non-beneficiary respondents, data reveals that major constraints perceived by the overall respondents were 'unavailability of micronutrient in market' (57.22 MPS) followed by 'price of fertilizers is high (55.82 MPS) were ranked first and second, respectively. While 'non-availability of NPK combination fertilizer' (49.99 MPS) was ranked third and 'sometimes adequate quantity of fertilizers are not available in the market' (48.32 MPS) was ranked fourth, respectively.

The value of rank correlation $\left(\mathrm{r}_{\mathrm{s}}\right)$ between beneficiary and non-beneficiary was 0.6 which was found non-significant, leading to conclusion that there was a similarity in rank assignment pattern of marketing constraints of beneficiary and non-beneficiary farmers about soil health card scheme, though there was a difference in the magnitude of MPS of beneficiary and non-beneficiary farmers. Thus, from the above findings it may be concluded that majority of the respondents reported that unavailability of micronutrient in market, price of recommended fertilizers is high and non-availability of NPK combination fertilizer were the major constraints. The findings are in accordance with the findings of Bunkar (2018) who found that non-availability of NPK combination of fertilizer followed by unavailability of micro nutrients in market were the major constraints faced by the farmers in adoption of SHCs.

\section{Socio-personal and Psychological Constraints}

The data in Table 4 reveals that major constraints perceived by the beneficiary respondents were 'lack of motivation' (56.11 MPS) ranked first followed by 'lack of education among farmers' (52.22 MPS) ranked second, 'negative attitude of old aged farmers towards SHCs' (46.11 MPS) ranked third, and 'lack of awareness regarding SHCs' (36.66 MPS) ranked fourth, 'lack of support of family members' (34.00 MPS) ranked fifth, 'selfish motives of agriculture officers' (30.55 MPS) ranked sixth and 'lack of interest in SHCs' (28.22 MPS) ranked seventh, respectively. The data in Table 4 also indicates that major constraints perceived by the non-beneficiary respondents were 'negative attitude of old aged farmers towards SHCs' (75.55 MPS) ranked first followed by 'lack of motivation' (74.44 MPS) ranked second, 'lack of education among farmers' (73.88 MPS) ranked third, 'lack of support of family members' (72.33 MPS) ranked fourth, 'lack of awareness regarding SHCs' (68.33 MPS) ranked fifth, 'lack of interest in SHCs' (66.11 MPS) ranked sixth and 'selfish motives of agriculture officers' (57.22 MPS) ranked seventh. 
Table.1 Ranking of items under technical constraints

\begin{tabular}{|c|c|c|c|c|c|c|c|}
\hline \multirow{3}{*}{$\begin{array}{c}\text { S. } \\
\text { No. }\end{array}$} & \multirow[t]{3}{*}{ Technical Constraints } & \multicolumn{6}{|c|}{ Respondents } \\
\hline & & \multicolumn{2}{|c|}{$\begin{array}{l}\text { Beneficiary } \\
\text { Respondents } \\
(\mathbf{n}=60)\end{array}$} & \multicolumn{2}{|c|}{$\begin{array}{l}\text { Non-beneficiary } \\
\text { Respondents } \\
(\mathbf{n}=60)\end{array}$} & \multicolumn{2}{|c|}{$\begin{array}{c}\text { Overall } \\
\text { Respondents } \\
(\mathbf{N}=\mathbf{1 2 0})\end{array}$} \\
\hline & & MPS & Rank & MPS & Rank & MPS & Rank \\
\hline 1. & $\begin{array}{l}\text { Time gap between soil } \\
\text { sample taken and issuing card } \\
\text { is very long }\end{array}$ & 30.50 & IV & 78.77 & III & 54.63 & III \\
\hline 2. & $\begin{array}{l}\text { Improper information about } \\
\text { micronutrient status in soil }\end{array}$ & 50.00 & I & 80.66 & II & 65.33 & II \\
\hline 3. & $\begin{array}{l}\text { Lack of knowledge about the } \\
\text { importance of micronutrients }\end{array}$ & 45.44 & II & 87.55 & I & 66.49 & I \\
\hline 4. & $\begin{array}{l}\text { Lack of knowledge about } \\
\text { scientific method of } \\
\text { collection of soil sample }\end{array}$ & 36.11 & III & 52.77 & IV & 44.44 & IV \\
\hline & Pooled & 40.51 & & 74.93 & $/$ & 57.72 & \\
\hline
\end{tabular}

Table.2 Ranking of Items under Administrative Constraints

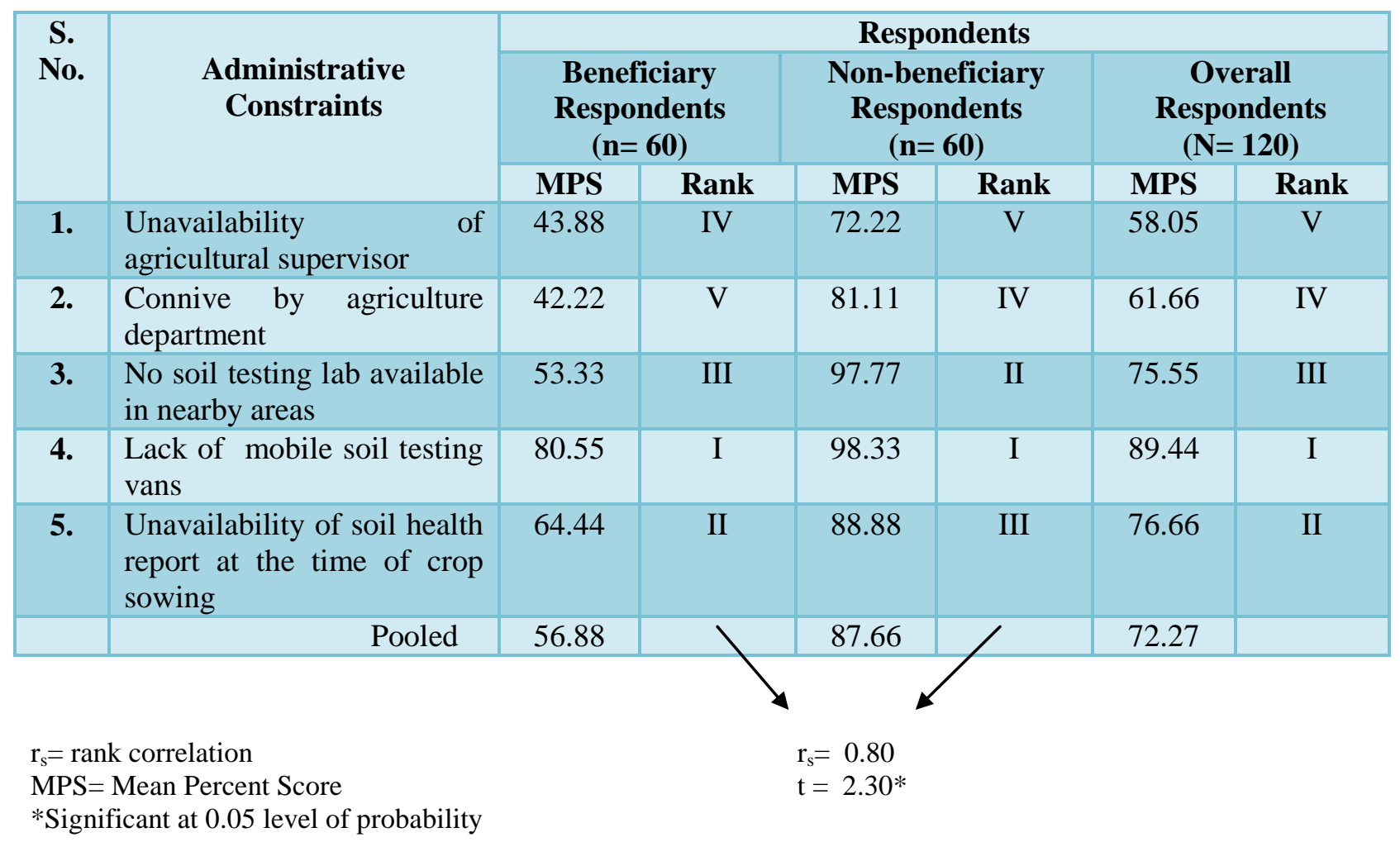


Table.3 Ranking of items under marketing constraints

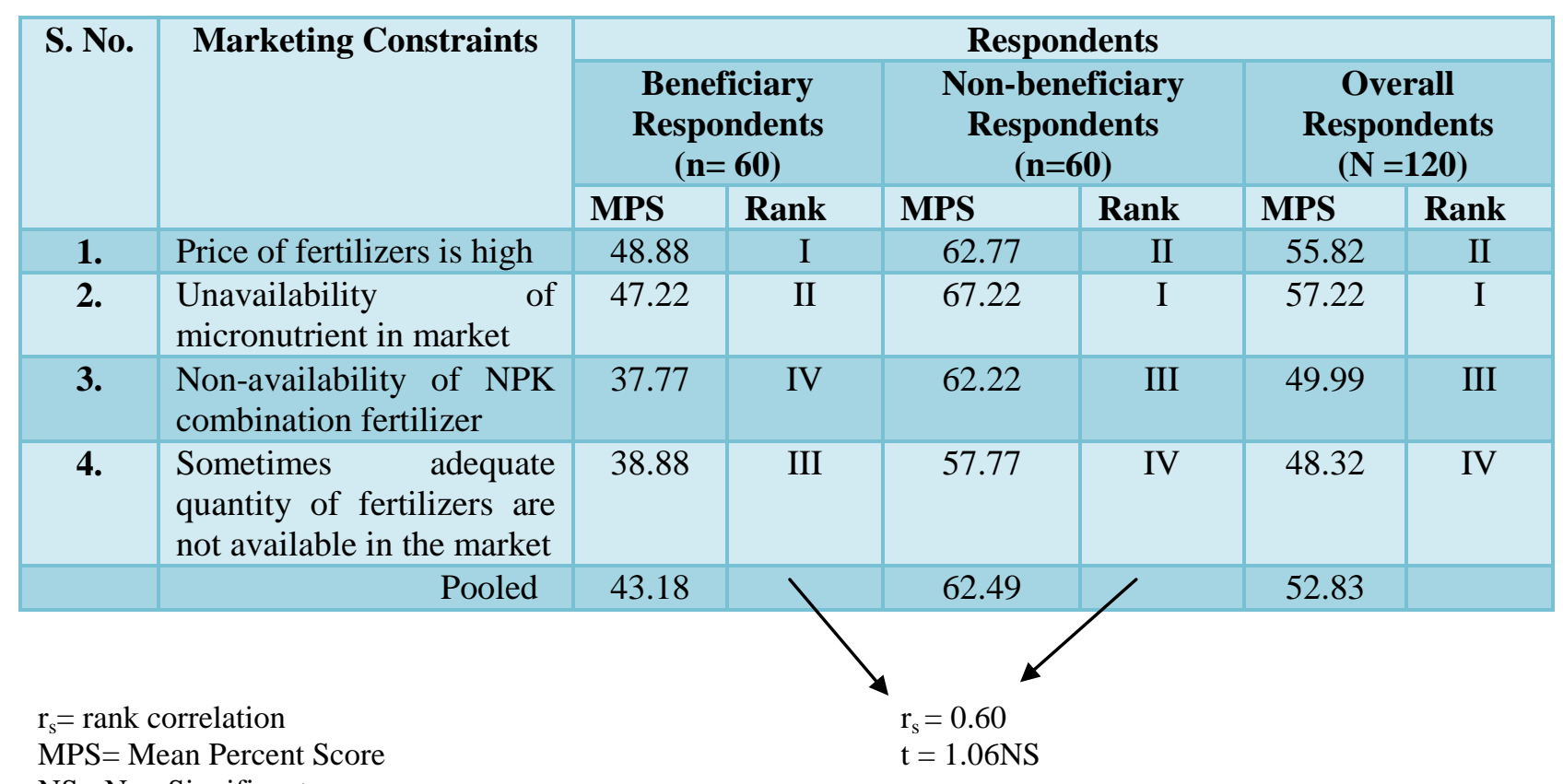

NS= Non Significant

Table.4 Ranking of items under socio-personal and psychological constraints

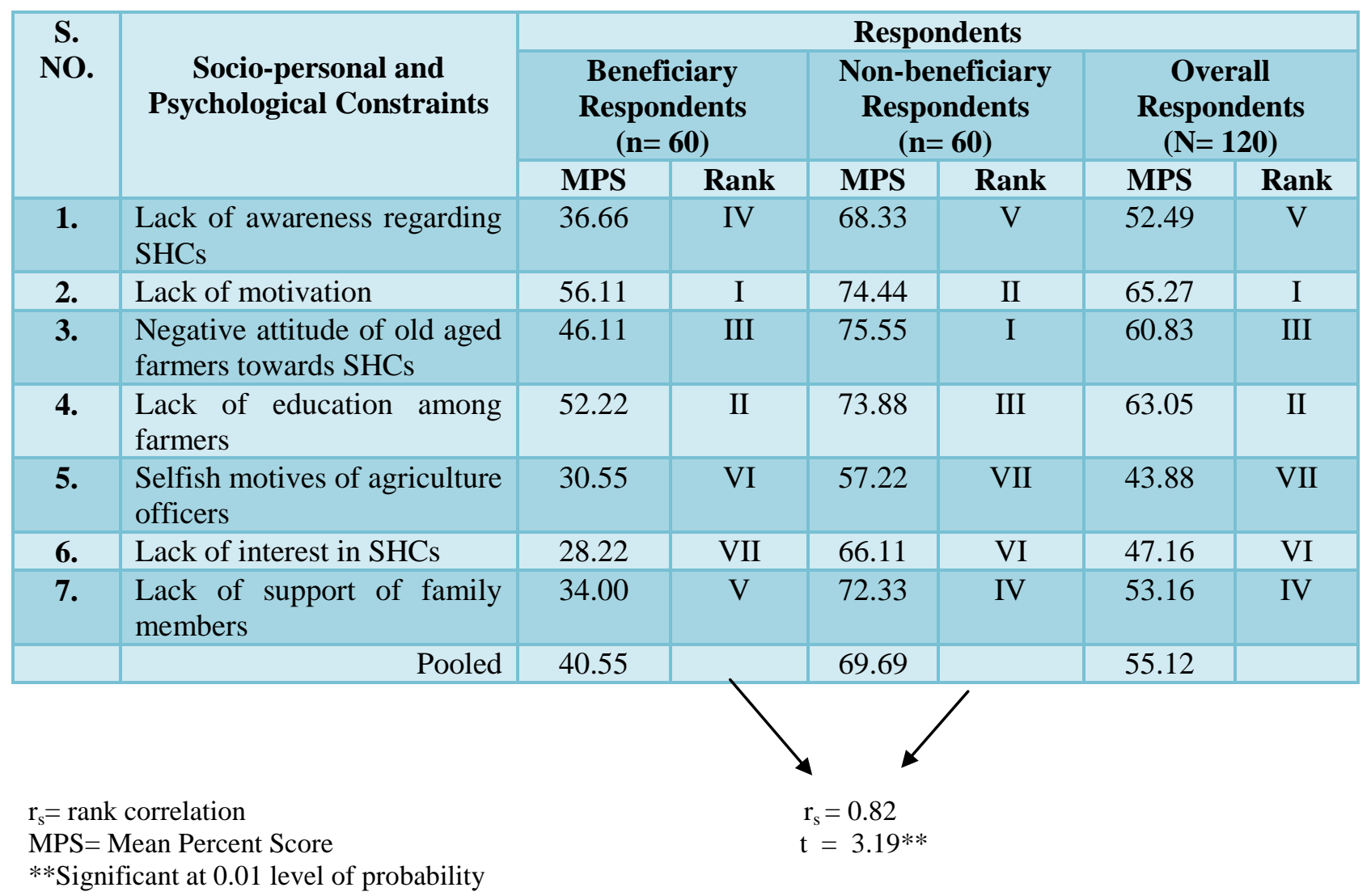


Further, Table 4 also depicts that major constraints faced by overall respondents were 'lack of motivation' (65.27 MPS) ranked first followed by 'lack of education among farmers' (63.05 MPS) ranked second, 'negative attitude of old aged farmers towards SHCs' (60.83 MPS) ranked third, 'lack of support of family members' (53.16 MPS) ranked fourth, 'lack of awareness regarding SHCs'(52.49 MPS) ranked fifth and 'lack of interest in SHCs' (47.16 MPS) ranked sixth. The constraint viz. 'selfish motives of agriculture officers' (43.88 MPS) was perceived least important by the overall respondents in the study area as they had assigned last rank to this constraint. Here, the value of calculated rank correlation $\left(r_{s}\right)$ was 0.82 which was positive and significant at one per cent level of significance, leading to conclusion that there was a similarity in rank assignment pattern of socio-personal and psychological constraints of beneficiary and non-beneficiary farmers about Soil Health Card scheme, though there was a difference in the magnitude of MPS of beneficiary and non-beneficiary farmers. The findings are supported by the findings of Patel (2013), Mukati (2016), Bunkar (2018) and Rathore (2018) who revealed that lack of awareness regarding SHCs and lack of education among farmers were the major socio-personal and psychological constraints faced by the respondents in the adoption of SHCs.

In conclusion this study provided the analysis of the constraints being faced by the farmers in Sri Ganganagar district of Rajasthan. The most important constraints faced by the respondents in the adoption of Soil Health card scheme were "lack of knowledge about the importance of micronutrients", "lack of mobile soil testing vans", "unavailability of micronutrient in market" and "lack of motivation". This might be due to the reason that farmers in the study area were not aware about the right procedures involved in the adoption of soil health card scheme. So, in order to mitigate these constraints farmers may be made aware about the importance of soil health card by State Government through trainings and awareness camps. Government should also take the necessary step to ensure the availability of mobile testing vans and micronutrients in the villages.

\section{References}

Anonymous (2015) Operational Guidelines for Implementation of Centrally Sponsored Scheme: Soil Health Card. Ministry of Agriculture and farmers welfare. Government of India.

Anonymous (2018) Press Information Bureau. Ministry of Agriculture and Farmers Welfare. Government of India.

Anonymous (2019) Agricultural and Processed Food Products Export Development Authority (APEDA), 2019: Accessed Feb. 7, 2019; http://apeda.gov.in.

Bunkar, D.K. (2018) Awareness about soil health card scheme among the farmers of Jaipur district of Rajasthan. M.Sc. (Ag.) Thesis, (Unpub.) SKNAU, Jobner.

Gopikrishna, S.R. (2012) "Soil health card support system." Economic and political weekly 47(29):24-26.

Hedge, D. M. and Sudhakarbabu S. N. (2004) Role of balanced fertilization in improving crop yield and quality. Fertilizer News, 49(12):113-114.

Lamkane, Y.S. (2018) Attitude of farmers towards recommendation of soil health card by the farmers of Aurangabad district of Maharashtra. M.Sc. (Agri.) Thesis, (Unpub.) VNMKV, Latur.

Mukati, A. (2016) Farmers perception regarding soil health card a study in Tikamgarh district of Madhya Pradesh. M.Sc. (Agri) Thesis, (Unpub.) Jawaharlal Nehru Krishi 
Vishwavidyalaya, Madhya Pradesh.

Patel, N.G. (2013) Attitude of the farmers towards soil health card programme. M.Sc. (Agri.) Thesis, (Unpub.) Anand Agricultural University, Gujarat.

Rathor, V. (2018) Farmers perception towards soil health card in Jabalpur district of Madhya Pradesh. M.Sc. (Agri.)
Thesis, (Unpub.) JNKVV, Jabalpur, M.P.

Tanwar, S. P. S. and Biswas, B. C. (2005) Strategies for food security and agricultural sustainability in changing scenario. Fertilizer News, 50(2): 2528.

\section{How to cite this article:}

Sheetal, Manmeet Kaur and Diksha Sharma. 2020. Constraints Faced by the Farmers in Adoption of Soil Health Card Scheme. Int.J.Curr.Microbiol.App.Sci. 9(09): 100-108. doi: https://doi.org/10.20546/ijcmas.2020.909.012 